\title{
PESQUISA CIENTÍFICA E PUBLICAÇÕES
}

\author{
Ricardo Guilherme VIEBIG *
}

Em nosso crescimento e desenvolvimento como seres humanos, desde pequenos, somos alvos ou nos utilizamos de pesquisas para enriquecer o conhecimento sobre nós mesmos e do mundo que nos cerca. Somos bombardeados por informações nem sempre verdadeiras e, por vezes, influenciados pelas mesmas, tomamos decisões nem sempre acertadas. Na carreira médica, isto pode ter graves implicações e por isto devemos ser treinados para entender, criticar, analisar tais pesquisas e também como fazê-las, pois assim aguçaremos mais ainda nossa visão científica.

Em síntese, os objetivos principais da pesquisa científica são: comprovar uma hipótese; explicar um fenômeno; quantificar uma ação; comparar situações iguais ou diferentes sob aspectos diversos; demonstrar novos meios ou instrumentos de pesquisa; estudar populações; verificar resultados de uma ação. Está implícito que toda pesquisa deverá ter seu resultado divulgado caso contrário não há sentido em realizá-la.

Cabe às escolas médicas, desde as ciências básicas, ensinar e treinar os futuros médicos para a realização de pesquisas. Incentivar a leitura de artigos e até mesmo incluí-los em protocolos de pesquisa para que o treinamento seja intenso. Infelizmente não é a realidade da maioria das escolas médicas do país. Fica então, para os programas de pós-graduação tal tarefa, excluindo-se os programas de residência que, na maioria, formam especialistas práticos, com pouco ênfase à pesquisa.

Os objetivos principais do autor de uma publicação científica são: instruir; ser lido; ser comparado; ser criticado; ser imitado; ser polêmico e, principalmente, SER CITADO.

O quê uma revista científica deseja dos autores? Em síntese, trabalhos que tragam IMPACTO (termo que significa o quão penetrante é a revista em número de leitores e citações por outros pesquisadores e periódicos). São desejados: artigos originais importantes, artigos curiosos e relevantes, artigos sobre novos tratamentos e métodos, autores consagrados, textos em inglês e finalmente que os trabalhos estejam de ACORDO com as NORMAS da Revista.

Ao receber um trabalho ou artigo para publicação, a maioria das revistas usa um sistema de julgamento conhecido como "peer review" (revisão por pares), que consiste na escolha de dois ou mais pesquisadores renomados da área que, por critérios estabelecidos pelos editores, julgam o trabalho, levando em conta inúme- ros aspectos tais como forma, estrutura, linguagem, metodologia, discussão e a relevância (impacto) para publicação. Os trabalhos são enviados a esses julgadores sem identificadores possíveis dos autores (nome, local da pesquisa, etc), tornando assim, possível um parecer imparcial sobre o trabalho. Eventualmente, além do corpo fixo dos revisores, as revistas podem solicitar pareceristas esporádicos (ad hoc) .

As barreiras iniciais à publicação começam pela inibição da escrita e pela dificuldade de comunicação de uma idéia. O desconhecimento da técnica e uma orientação incompleta e inadequada são fatores frequentes encontrados. $\mathrm{O}$ autoditatismo é muito forte pelas razões anteriores apresentadas e dificultam por demais as publicações. Soma-se a isto as dificuldades com a escrita na língua inglesa (terminologia médica), o desconhecimento da linha editorial da revista, incluindo o rigor científico exigido pelos editores, além de certa xenofobia, em se tratando de periódicos internacionais.

Os tipos de pesquisa ou textos mais comuns são:

Artigo original: geralmente oriundo de tese de mestrado, doutorado ou de linha de pesquisa de um departamento. Sua principais características são: pesado, completo, muitas informações, tabelas, gráficos, figuras e citações. Há uma tendência a perder-se do foco principal, quando "enxutos" para publicação .

Estudo retrospectivo: o mais comum contém levantamento de dados de determinada ação ou relevam algum fato específico e significativo ou procuram demonstrar a eficiência ou a importância de determinado departamento. Geralmente pecam por metodologias confusas.

Estudo prospectivo: geralmente linha de pesquisa. Inclui testes terapêuticos (ensaios clínicos) e novas técnicas. Suas dificuldades atuais são éticas e necessitam de Consentimento Esclarecido e Informado, além da Aprovação do CEP (Comitê de Ética em Pesquisa). Por vezes envolvem conflitos de interesse que devem ser descritos obrigatoriamente.

Estudo experimental: proveniente de linha de pesquisa, geralmente em animais. Necessita de aprovação de $\mathrm{CEP}$ e atender às normas de pesquisa em animais. Em seres humanos tem critérios éticos rigorosos.

Outros tipos menos valorizados pelas revistas e pela comunidade científica são: série de casos, relato de caso, "consensos" e validação de questionários. Artigos de revisão ou meta-análise e editoriais, são elaborados a pedido ou convite dos editores. 
Algumas recomendações dos Editores dos ARQUIVOS de GASTROENTEROLOGIA:

Escreva o texto para ser lido. Tenha cuidado com a fluência do texto, seguindo uma linha de raciocínio. Evite siglas excessivas, focando-se na idéia principal do trabalho. Pense e tenha um bom título e ótimo resumo (geralmente, o leitor só lê e se interessa pelo trabalho inteiro se estes forem convidativos). Evite ser prolixo ou condensado demais .

Escolha o periódico mais adequado a sua publicação. Leia com muita atenção as instruçôes aos autores (uma revista é diferente da outra). Ao verter para o inglês, tanto o trabalho como o resumo, submeta-os a avaliação por profissional experiente com o inglês médico. Leia o trabalho várias vezes: em velocidade normal para perceber o sentido das frases e a falta de alguns termos; releia-o lentamente para verificar erros de escrita. $\mathrm{Na}$ era do computador muitas frases "somem", geralmente no início ou fim de parágrafos. Use uma régua para identificar palavra por palavra, linha por linha. Faça uma leitura para alguém que esteja acompanhando o texto. Faça as mudanças com marcadores e de forma bem clara. Releia quantas vezes forem necessárias.

Tenha certeza de que seu trabalho será rejeitado se: contiver frases sem nexo ou de sentido ambíguo; tiverem inseridas referências que não tenham conexão com a frase ou afirmação ou em local inadequado; contiver referências que não estejam citadas no texto; as instruções aos autores forem ignoradas; substituir métodos por resultados ou vice-versa; as páginas não tiverem numeração; as figuras e tabelas estiverem inseridas no corpo do texto; a lista de referências bibliográficas for enviada do jeito que achar melhor; o resumo for cópia literal de trechos do trabalho; esquecer-se de enviar a página inicial, o título em inglês ou português, o resumo na segunda língua, se necessário... ou enviar a "cover letter" para um editor já falecido ou não mais vinculado editorialmente à revista.

Por fim, a última recomendação: ler muitos trabalhos e analisá-los de forma crítica, procurando seus defeitos e suas qualidades. 